\title{
PENGUATAN KAPASITAS PEMERINTAH DESA WANAGIRI MELALUI PENDAMPINGAN PENYUSUNAN RPJMDES DAN PERTANGGUNGJAWABAN DANA DESA
}

\author{
Edy Sujana, Ni Made Suci, I Nyoman Putra Yasa, \\ Nyoman Ayu Wulan Trisna Dewi \\ Universitas Pendidikan Ganesha, Indonesia \\ edy.s@undiksha.ac.id
}

\begin{abstract}
The Village Medium Term Development Plan (RPJMDes) is an elaboration of the vision and mission for the village in the welfare of the village community. The Wanagiri Village Government encountered problems in the preparation of the village medium term development plan due to the unavailability of up-to-date village profile data and the insufficient capacity of village officials to prepare the village medium term development plan. Another problem is the lack of understanding of village officials regarding village financial management, so that village officials experience difficulties in managing village funds. This service program aims to strengthen the capacity of the Wanagiri Village Government Management by assisting in the preparation of the Village Development Plan (RPJMDes) and Village Fund Accountability. This program is implemented in the form of training and mentoring. The results of this activity were in the form of increased understanding of village officials in preparing the RPJMDes and the accountability of village funds. The target of this activity is the realization of the independence of village officials in preparing the village medium term development plan and accountability for village funds in the future.
\end{abstract}

Keywords: village development plan, accountability of village funds, capacity of village officials

\begin{abstract}
Abstrak
Rencana Pembangunan Jangka Menengah Desa (RPJMDes) merupakan penjabaran visi dan misi kepada desa dalam mensejahterakan masyarakat desa. Pemerintah Desa Wanagiri mengalami permasalahan dalam penyusunan RPJMDes karena tidak tersedianya data profil desa terkini dan kurang memadainya kemampuan perangkat desa dalam menyusun RPJMDes. Permasalahan lainnya adalah kurangnya pemahaman perangkat desa terkait manajemen keuangan desa, sehingga perangkat desa mengalami kesulitan dalam mengelola dana desa. Program pengabdian ini bertujuan untuk menguatkan kapasitas manajemen pemerintahan Desa Wanagiri melalui pendampingan penyusunan RPJMDes dan Pertanggungjawaban Dana Desa. Program ini dilaksanakan dalam bentuk pelatihan dan pendampingan. Hasil kegiatan ini berupa meningkatnya pemahaman perangkat desa dalam melakukan penyusunan RPJMDes dan pertanggungjawaban dana desa. Target capaian kegiatan ini adalah terwujudnya kemandirian perangkat desa dalam menyusun RPJMDes dan Pertanggungjawaban dana desa di masa yang akan datang.

Kata Kunci: rencana pembangunan desa; pertanggungjawaban dana desa, kapasitas pemerintah desa
\end{abstract}

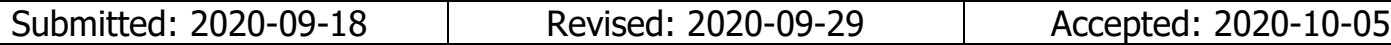

\section{Pendahuluan}

Rencana Pembangunan Jangka Menengah Desa (RPJMDes) merupakan output dari manajemen strategis di sektor pemerintahan, khususnya di pemerintahan tingkat desa. Strategi organisasi terdiri dari tiga elemen yakni (a) tujuan, (b) konten, dan (c) proses (Andrews et al., 2012). Tujuan terkait dengan "apa yang ingin dicapai", jika diaplikasikan 
dalam RPJMDes, maka tujuannya berupa apa yang ingin dicapai organisasi dalam jangka waktu 6 tahun ke depan, sementara konten terkait dengan cara-cara atau alternatifalternatif untuk dapat mencapai tujuan, sedangkan proses berkaitan dengan proses untuk menentukan langkah atau alternatif dalam mencapai tujuan. Maksud dari penyusunan RPJMDes ini adalah memberikan visi, misi, tujuan, sasaran, dan strategi bagi penyelenggaraan pemerintahan dan pembangunan di pemerintahan desa yang harus dilaksanakan secara terpadu, sinergis, harmonis, dan berkesinambungan, sementara tujuan dari RPJMDes adalah (a) menerjemahkan visi dan misi kepala desa ke dalam tujuan dan sasaran pembangunan periode tahun 2020-2025, yang disertai dengan program prioritas, (b) merumuskan rancangan kerangka perekonomian desa serta pembiayaan pembangunan untuk periode Tahun Anggaran 2020-2025, dan (c) menetapkan berbagai program prioritas yang disertai dengan indikasi pagu anggaran dan target indikator kinerja yang akan dilaksanakan pada tahun 2020-2025.

Pada era otonomi desa yang dipertegas melalui Undang-Undang No. 6 tentang Desa, pemerintah desa dituntut untuk memiliki kemampuan dalam menjalankan tugas manajemen pemerintahan desa, yakni manajemen perencanaan pembangunan, manajemen administrasi desa, dan manajemen pengelolaan keuangan pemerintah desa. Akan tetapi, masih ditemukannya permasalahan terkait belum memadainya kemampuan perangkat desa dalam menjalankan fungsi manajemen pemerintahan, yaitu : (1) manajemen perencanaan pembangunan desa, (2) manajemen administrasi desa dan (3) manajemen pengelolaan keuangan pemerintah desa (Noor, Firdaus, dan Yopiannor, 2019).

Desa Wanagiri merupakan Desa Dinas yang baru saja melaksanakan Pemilihan Kepala Desa serentak bersama beberapa Desa di Kabupaten Buleleng. Berdasarkan Undang-Undang Nomor 6 Tahun 2014 tentang Desa, maka Kepala Desa wajib untuk menyusun Rencana Pembangunan Jangka Menengah Desa (RPJMDes) sebagai penjabaran Visi dan Misi Kepala Desa yang baru dalam mensejahterakan masyarakat Desa. Berdasarkan Permendagri 114/2014, perencanaan pembangunan desa adalah tahapan kegiatan yang diselenggarakan oleh pemerintah Desa dengan melibatkan Badan Permusyawaratan Desa dan unsur masyarakat secara partisipatif guna pemanfaatan dan pengalokasian sumber daya desa dalam rangka mencapai tujuan pembangunan desa. Kepala Desa yang terpilih harus segera membentuk Tim Penyusun RPJMDes dan melaporkan RPJMDes yang telah disahkan paling lambat 3 bulan setelah pelantikan.

Data awal yang berhasil dikumpulkan saat observasi di Desa Wanagiri, terungkap bahwa Aparat Desa, dalam hal ini Sekretaris Desa dan jajarannya mengalami masalah krusial dalam administrasi pemerintahan desa yaitu kesulitan dalam menyusun dan menerjemahkan Visi dan Misi Kepala Desa terpilih ke dalam RPJMDes. Kesulitan dalam penyusunan RPJMDes disebabkan karena ketiadaan data profil desa dan belum memadainya kompetensi Aparat Desa Wanagiri. Permasalahan yang kedua terkait dengan ketakutan mengeksekusi anggaran dan pertanggungjawaban anggaran yang disebabkan karena kekurangpahaman terhadap aturan yang berlaku dalam pengelolaan anggaran desa. Penyusunan rencana pembangunan desa tidak bisa dilaksanakan dengan baik, tanpa adanya data dan informasi lengkap baik dalam penyelenggaraan pemerintahan Desa, organisasi dan tata laksana pemerintahan desa, keuangan desa, profil desa dan 
informasi lain terkait dengan penyelenggaraan pemerintahan dan pemberdayaan masyarakat (Sulaiman, 2018). Penyusunan dan pendayagunaan data Profil Desa merupakan suatu kegiatan pengumpulan, pengolahan dan publikasi data Profil Desa serta berbagai upaya pemanfaatan data tersebut dalam sistem perencanaan dan evaluasi kinerja penyelenggaraan pemerintahan, pembangunan dan pembinaan kemasyarakatan (Achsin, Cangara, dan Unde, 2016). Dalam hal pembangunan desa, instrumen penting yang perlu diketahui adalah bagaimana sebenarnya permasalahan yang dialami oleh desa dan seberapa besar atau kuat potensi desa yang dimiliki. Penyusunan Indeks Desa Membangun dimaksudkan untuk menyediakan ukuran yang mampu melihat posisi dan status desa serta arah tingkat kemajuan dan kemandirian Desa (Setyobakti, 2017)

Data profil Desa Wanagiri terakhir diperbaharui tahun 2015 sehingga kondisi umum Desa Wanagiri untuk tahun 2019 belum diketahui. Profil Desa seperti yang diamanatkan oleh Peraturan Menteri Dalam Negeri Nomor 12 Tahun 2007 tentang Pedoman Penyusunan dan Pendayagunaan Profil Desa dan Kelurahan, merupakan data yang sangat penting dalam menyusun RPJMDes. Profil Desa yang akurat akan memberikan informasi yang tepat sebagai dasar dalam menemukan solusi untuk mengatasi permasalahan yang ada di Desa.

Penyusunan Rencana Pembangunan Desa dan pertanggungjawaban dana desa tidak merupakan hal yang mudah. Kegiatan tersebut membutuhkan perhatian khusus berupa kemampuan pengetahuan dan keterampilan tentang perencanaan pembangunan desa dan kepekaan terhadap kondisi desa (Harun, Rasid, dan Aramli, 2019). Penguatan kapasitas pemerintah desa sangat perlu dilakukan untuk meminimalisasi permasalahan tersebut. Pengembangan kapasitas merupakan sebuah upaya yang bertujuan untuk mengembangkan suatu ragam strategi guna meningkatkan efisiensi, efektivitas dan responsivitas kinerja pemerintah, salah satunya dapat dilakukan melalui pelatihan (Nugroho, Wijaya, dan Said, 2015). Untuk memperkuat kapasitas pemerintah desa dalam hal menjalankan fungsi manajemen pemerintah, salah satunya dapat dilaksanakan melalui program kegiatan pelatihan dan pendampingan penyusunan Rencana Pembangunan Jangka Menengah Desa dan Pertanggungjawaban dana desa. Program pelatihan penyusunan RPJMDes dapat memberikan kemudahan dalam penulisan, teknik perencanaan serta pemecahan analitis atas permasalahan pembangunan yang dihadapi desa (Tampubolon, 2019). Program pelatihan pengelolaan dana desa memberikan manfaat berupa: peningkatan sistem akuntabilitas pengelolaan keuangan desa, peningkatan keterampilan aparatur pemerintah desa dalam penatausahaan keuangan desa, terhindar dari masalah hukum terkait dengan pengelolaan keuangan desa, dan meningkatnya kepercayaan masyarakat terhadap aparatur desa (Putra, Budianto,dan Maulidasari, 2018). Program Pengabdian kepada masyarakat berupa pelatihan dan pendampingan ini dapat memberikan wawasan dan pengetahuan baru yang belum diketahui sebelumnya (Bandiyah, 2016).

Berdasarkan uraian diatas, Pengabdian kepada Masyarakat ini bertujuan untuk:

a. Memberikan Pelatihan dan Pendampingan dalam menyusun Profil Desa terbaru untuk Desa Wanagiri termasuk penyusunan Indeks Desa Membangun dan Evaluasi Perkembangan Desa guna mengetahui kondisi perkembangan desa 
b. Memberikan Pelatihan dan Pendampingan dalam menyusun Dokumen RPJMDes sebagai penjabaran Visi dan Misi Kepala Desa Baru Desa Wanagiri 2019-2025

c. Memberikan pelatihan dan pendampingan manajemen keuangan desa.

Dengan adanya program pelatihan dan pendampingan ini diharapkan dapat mewujudkan kemandirian perangkat desa dalam melakukan penyusunan rencana pembangunan desa dan pertanggungjawaban dana desa.

\section{Metode}

Kegiatan pengabdian kepada masyarakat ini terdiri dari tiga tahapan, yakni tahap persiapan, tahap pelaksanaan, dan tahap evaluasi. Tahap persiapan dalam kegiatan pengabdian kepada masyarakat ini meliputi penyiapan berbagai administrasi yang mungkin diperlukan, koordinasi dengan Perangkat Desa Wanagiri, Penyiapan materi penyuluhan dan pelatihan, penyiapan narasumber, penyiapan jadwal pelatihan, dan penyiapan kelengkapan lainnya.

Tahap Pelaksanaan Pelatihan dan Pendampingan tentang penyusunan profil desa, RPJMDes, dan pertanggungjawaban dana desa di Desa Wanagiri dilaksanakan pada bulan ke-4 sampai dengan bulan ke-6. Metode kegiatan yang digunakan dalam kegiatan ini berupa pelatihan. Pelatihan diberikan kepada perangkat desa Wanagiri. Untuk tercapainya tujuan kegiatan ini digunakan ceramah, diskusi, dan konsultasi. Tahap implementasi kegiatan ini adalah:

a. Pemberian pengetahuan tentang Indeks Desa Membangun dan Evaluasi Pembangunan Desa dalam menunjang ketersediaan informasi pada profil desa yang dapat dijadikan informasi dalam penyusunan RPJMDes.

b. Pemberian pengetahuan tentang Rencana Pembangunan Jangka Menengah Desa (RPJMDes)

c. Pemberian pengetahuan tentang manajemen keuangan desa

d. Pemberian pelatihan dan pendampingan penggunaan aplikasi E-IDM untuk menghitung indeks desa membangun dan aplikasi E-EPD untuk menghitung evaluasi perkembangan desa kepada perangkat desa

e. Pemberian pelatihan dan pendampingan penyusunan RPJMDes

f. Pelatihan dan Pendampingan Manajemen Keuangan Desa

Khalayak sasaran adalah aparatur Desa Wanagiri sebagai penyusun dan pengguna anggaran, Badan Permusyawaratan Desa (BPD), serta masyarakat desa. Kerangka pemecahan masalah yang ditempuh berdasarkan permasalahan yang dihadapi mitra adalah sebagai berikut: (1) Ceramah, dalam hal ini aparatur desa diberikan materi tentang pentingnya manajemen pemerintahan desa, penyusunan rencana pembangunan desa, dan manajemen keuangan desa (2) pelatihan, dalam kegiatan ini peserta melakukan penggunaan aplikasi E-IDM dan E-EPD untuk mengetahui status desa, serta praktek penyusunan RPJMDes dan (3) Pendampingan bagi khalayak sasaran dalam menggunakan aplikasi E-IDM dan E-EPD dan penyusunan RPJMDes.

Dalam tahap evaluasi yang dilakukan terkait evaluasi pemahaman khalayak sasaran terkait penyusunan profil desa, RPJMDes, dan pertanggungjawaban dana desa. Rancangan evaluasi yang dilaksanakan dalam kegiatan ini terdiri dari evaluasi proses dan 
produk. Evaluasi proses meliputi aktivitas peserta dalam mengikuti kegiatan, keberhasilan dapat dilihat dari keaktifan dalam bertanya dan berdiskusi, sedangkan evaluasi hasil dapat dilihat dari pemahaman dan kemampuan khalayak sasaran dalam penyusunan profil desa, RPJMDes, dan pertanggungjawaban dana desa.

\section{Hasil dan Pembahasan}

Penyusunan RPJMDes merupakan agenda wajib yang harus disusun setiap 6 (enam) tahun sekali di tingkat pemerintah desa, begitupula pada pemerintah Desa Wanagiri. Dalam penyusunan rencana pembangunan desa tersebut diperlukan berbagai informasi termasuk di dalamnya informasi terkait profil desa. Dalam dokumen profil desa itu sendiri juga memuat indeks desa membangun dan juga evaluasi perkembangan desa. Kapasitas desa yang memadai sangat diperlukan untuk dapat menyediakan informasiinformasi yang dibutuhkan dalam penyusunan perencanaan pembangunan desa sebagai salah satu agenda dalam menjalankan fungsi manajemen pemerintah. Selain itu, laporan pertanggungjawaban merupakan agenda wajib yang harus dilakukan setiap satu tahun anggaran. Untuk itu, kegiatan pelatihan dan pendampingan dilaksanakan dengan tujuan untuk menguatkan kapasitas pemerintah desa dalam menjalankan fungsi manajemen pemerintah, khususnya dalam menyusun profil desa sebagai informasi dasar dalam penyusunan perencanaan pembangunan desa penyusunan RPJMDes, dan pertanggungjawaban dana desa.

Pada bagian ini akan dipaparkan mengenai gambaran umum dan data yang diperoleh selama pelaksanaan kegiatan pengabdian kepada masyarakat. Kegiatan ini dilakukan dengan metode ceramah, pelatihan, dan pendampingan. Kegiatan ini merupakan pengabdian dalam upaya meningkatkan kapasitas pemerintah desa dalam menjalankan fungsi manajemen pemerintah desa. Kegiatan pengabdian kepada masyarakat ini diawali dengan penyiapan berbagai administrasi yang diperlukan dalam pelaksanaan pengabdian, melakukan koordinasi dengan perangkat Desa Wanagiri untuk menentukan jadwal pelaksanaan kegiatan, mempersiapkan materi penyuluhan, pelatihan dan pendampingan, serta menyiapkan narasumber yang memiliki kompetensi sesuai dengan materi pengabdian kepada masyarakat ini. Kegiatan pelatihan dan pendampingan ini berupaya untuk meningkatkan pemahaman perangkat desa dalam hal penyusunan profil desa, RPJMDes, dan Pertanggungjawaban dana desa. Terdapat 3 kegiatan dalam program pengabdian kepada masyarakat ini yakni, tahap penyuluhan, tahap pelatihan, dan tahap pendampingan.

1. Kegiatan Penyuluhan

Pelaksanaan kegiatan penyuluhan dilakukan dengan dua tahapan yakni tahap persiapan dan tahap pelaksanaan. Tahap persiapan meliputi pengkoordinasian peserta, waktu dan tempat pelaksanaan penyuluhan serta persiapan perlengkapan lainnya. Materi kegiatan penyuluhan disampaikan oleh ketua Tim Pengabdi. Dalam kegiatan penyuluhan ini dipaparkan mengenai urgensi penyusunan Rencana Pembangunan Jangka Menengah Desa dan Pertanggungjawaban penggunaan dana desa kepada perangkat desa Wanagiri. Pemaparan materi pertama dalam penyuluhan ini bermaksud untuk memberikan penekanan tujuan dan manfaat perencanaan pembangunan desa. Tujuan dari RPJMDes 
adalah (a) menerjemahkan visi dan misi kepala desa ke dalam tujuan dan sasaran pembangunan periode tahun 2020-2025, yang disertai dengan program prioritas, (b) merumuskan rancangan kerangka perekonomian desa serta pembiayaan pembangunan untuk periode Tahun Anggaran 2020-2025, dan (c) menetapkan berbagai program prioritas yang disertai dengan indikasi pagu anggaran dan target indikator kinerja yang akan dilaksanakan pada tahun 2020-2025. Dengan demikian, potensi desa unggul yang dimiliki oleh Desa Wanagiri, jika dikombinasikan dengan rancangan dokumen Rencana Pembangunan Jangka Menengah Desa (RPJMDes) yang mendukung pengembangan potensi-potensi desa tersebut, maka akan memberikan implikasi pada peningkatan kesejahteraan dan kemajuan Desa Wanagiri. Untuk itu sangat diperlukan penyusunan RPJMDes yang tepat. Dalam rangka penyusunan RPJMDes sangat diperlukan data terkait kondisi desa yang memadai. Dengan adanya aplikasi untuk menghitung Indeks Desa Membangun dan Evaluasi Pembangunan Desa secara cepat dan tepat, sehingga data dan informasi kondisi desa dapat tersedia dengan memadai. Pada kegiatan penyuluhan ini juga dipaparkan mengenai Indeks Desa Membangun dan Evaluasi Pembangunan Desa yang dihitung menggunakan aplikasi dalam menunjang ketersediaan informasi pada profil desa yang dapat dijadikan informasi dalam penyusunan RPJMDes.

Pemaparan materi terkait dengan pertanggungjawaban dana desa disampaikan langsung oleh ketua tim pengabdi. Dalam pemaparannya ditekankan bahwa sumber pendanaan dalam kegiatan di organisasi pemerintah berasal dari dana publik, untuk itu organisasi pemerintah berkewajiban untuk melaporkan dan mempertanggungjawabkan penggunaan dana tersebut sebagai bentuk akuntabilitas. Hasil kegiatan penyuluhan ini yakni memberikan wawasan yang lebih mendalam dan juga memberikan penekanan kepada perangkat desa terkait urgensi penyusunan RPJMDes dan pertanggungjawaban dana desa. Dengan adanya pemahaman terkait urgensi penyusunan RPJMDes dan pertanggungjawaban dana desa maka perangkat desa menyadari perlunya pengetahuan yang memadai terkait bagaimana teknis penyusunan RPJMDes yang baik serta bagaimana penyusunan pertanggungjawaban dana yang tepat

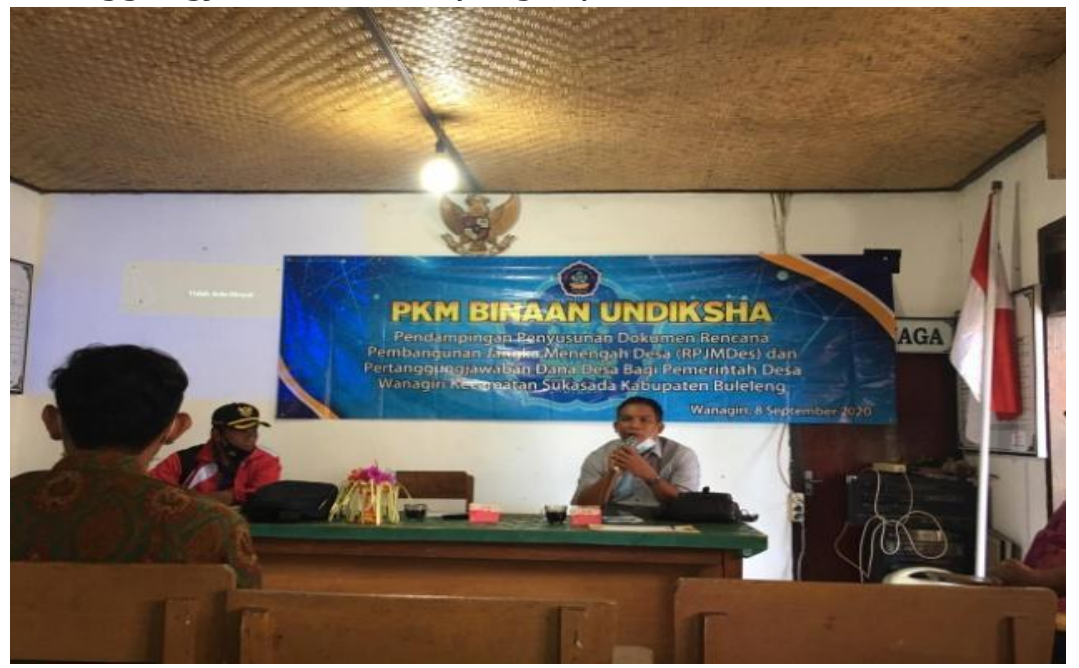

Gambar 1. Pemaparan Materi terkait Profil Desa, RPJMDes, dan Pertanggungjawaban Dana Desa 
BERNAS:

Jurnal Pengabdian Kepada Masyarakat

Vol.1 No. 4, October 2020, pp. 531-542

2. Kegiatan Pelatihan dan Pendampingan Penggunaan aplikasi E-IDM dan E-EPD

Pelatihan penggunaan aplikasi E-IDM dan E-EPD dipaparkan langsung oleh programmer yang membuat aplikasi tersebut dan didampingi langsung oleh ketua tim pengabdi. Pelaksanaan kegiatan pelatihan dan pendampingan penggunaan aplikasi E-IDM dan E-EPD diawali dengan tahap persiapan yang meliputi penyiapan materi, narasumber, waktu, dan tempat pelaksanaan. Tahap kedua adalah tahap pelatihan dan pendampingan dalam bentuk pelatihan pemahaman penggunaan aplikasi beserta tahapannya secara detail yang diawali dengan mengunduh dan menginstall aplikasi tersebut di dalam smartphone masing-masing serta menjelaskan masing-masing fitur yang terdapat di dalam aplikasi, dan cara pengisian atau penginputan data untuk memenuhi indikator indeks desa membangun ataupun evaluasi perkembangan desa. Indeks Desa Membangun itu sendiri dibentuk dari gabungan indeks Ketahanan Sosial, Indeks Ketahanan Ekonomi dan Indeks Ketahanan Ekologi. Para pesertapun memberikan respon bahwa penggunaan aplikasi ini sangat membantu dalam mempersiapkan data dan informasi terkait gambaran umum kondisi desa yang digunakan dalam penyusunan dokumen perencanaan pembangunan desa (RPJMDes).

Tahap ketiga pada kegiatan ini adalah tahap evaluasi. Hasil evaluasi dari kegiatan ini adalah meningkatkan kemampuan aparatur desa dalam menghitung indeks desa membangun dan evaluasi perkembangan desa dengan bantuan aplikasi E-IDM dan E-EPD. Perangkat desa telah mampu melakukan perhitungan indeks desa membangun dengan menginput berbagai data untuk memenuhi indikator-indikator dalam menilai status desa. 30 peserta yang mengikuti kegiatan ini telah mampu melakukan penghitungan indeks desa membangun melalui aplikasi E-IDM dan penghitungan evaluasi perkembangan desa melalui aplikasi E-EPD.

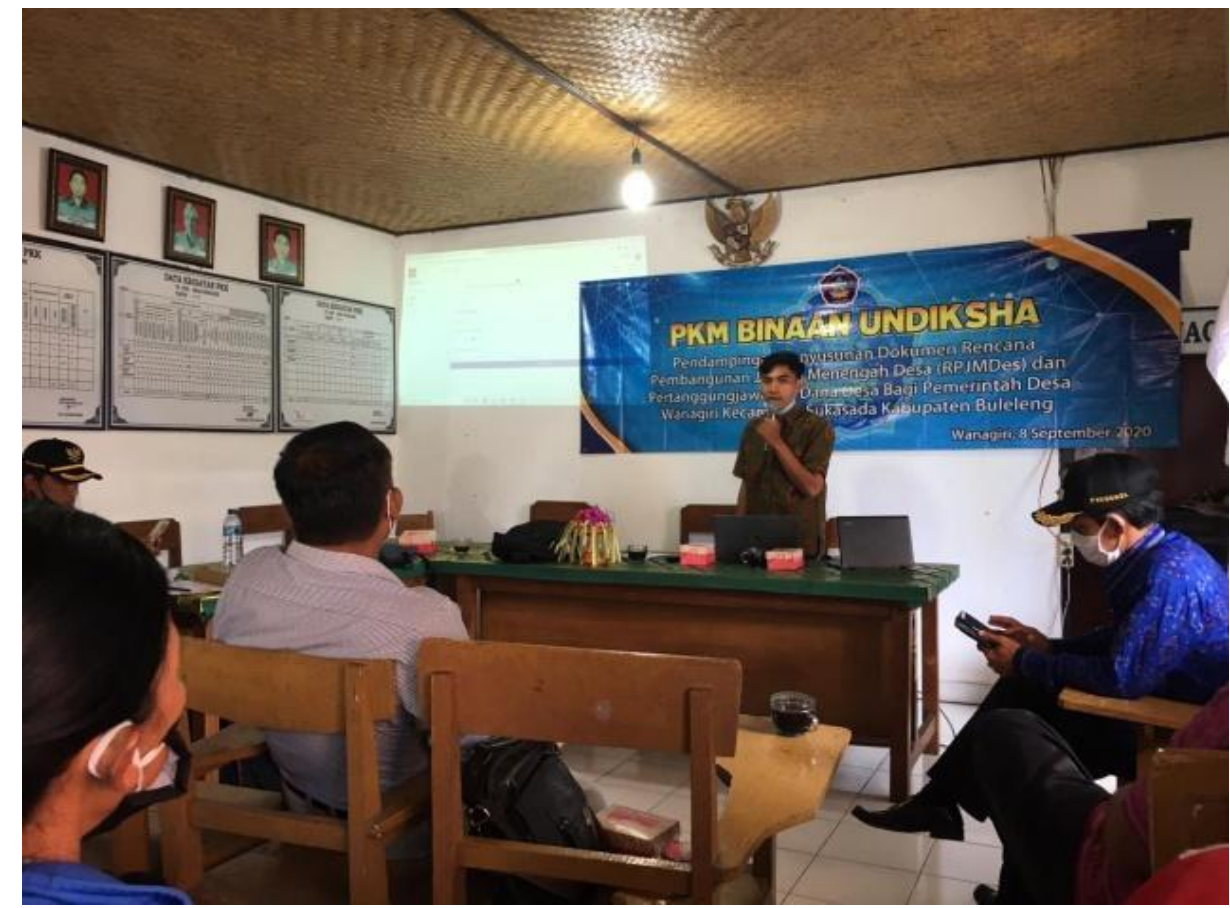

Gambar 2. Pelatihan penggunaan aplikasi E-IDM dan E-EPD 


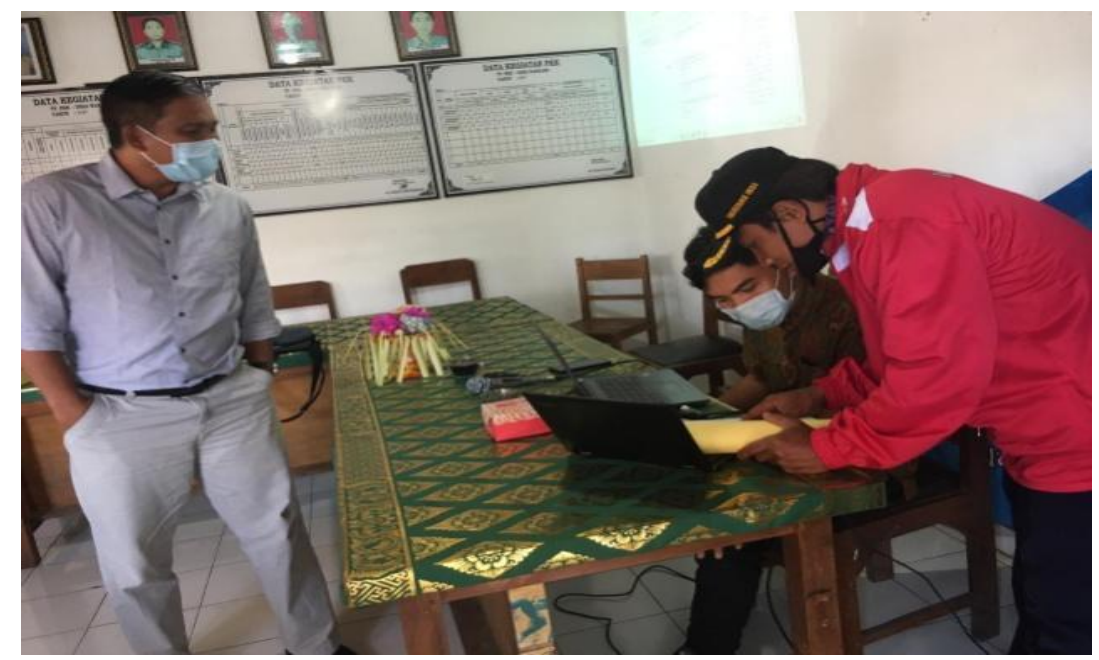

Gambar 3. Pendampingan penggunaan aplikasi E-IDM dan E-EPD

Dengan tersedianya data dan informasi terkait gambaran umum kondisi desa, maka perangkat desa dapat memanfaatkan informasi yang tersedia tersebut untuk menyusun kebijakan perencanaan pembangunan desa dan penganggaran yang sesuai dengan masalah yang dihadapi desa.

3. Kegiatan Pelatihan dan Pendampingan Penyusunan RPJMDes dan Pertanggungjawaban Dana Desa

Kegiatan pelatihan dan pendampingan ini diawali dengan tahapan persiapan, dilanjutkan dengan tahap pelaksanaan, dan diakhiri dengan tahapan evaluasi. Tahapan persiapan meliputi penyiapan materi pelatihan, persiapan peserta, koordinasi waktu dan tempat pelaksanaan kegiatan, serta penyiapan perlengkapan lainnya. Materi yang disampaikan terkait dengan teknis penyusunan Rencana Pembangunan Jangka Menengah Desa secara teoritis dan sesuai dengan aturan yang berlaku, termasuk didalamnya komponen-komponen dalam Rencana Pembangunan, langkah-langkah penyusunan perencanaan, siklus perencanaan, dan penyusunan visi, misi, tujuan, dan sasaran merupakan komponen yang tercantum dalam rencana pembangunan.

Pada pelaksanaan pelatihan dan pendampingan penyusunan RPJMDes diawali dengan memberikan ceramah terkait dengan teknis penyusunan perencanaan pembangunan serta komponen-komponen penting yang tercantum dalam dokumen perencanaan. Kegiatan berikutnya dilanjutkan dengan praktek penyusunan rencana pembangunan sederhana yang diawali dengan menyusun gambaran umum kondisi desa, kemudian dilanjutkan dengan analisis isu strategis desa berdasarkan analisis SWOT (Strength, Weakness, Opportunity, and Threat), kemudian diakhiri dengan perumusan perencanaan strategis yang nantinya dituangkan ke dalam bentuk program dan kegiatan yang tersusun dalam dokumen perencanaan.

Tahap kegiatan pelatihan dan pendampingan penyusunan RPJMDes diakhiri dengan melakukan evaluasi penyusunan RPJMDes melalui penskoran menggunakan skala likert (1-5) dan dianalisis menggunakan analisis deskriptif. Pelaksanaan kegiatan pelatihan dan pendampingan penyusunan RPJMDes dikatakan berhasil jika hasil evaluasi produknya 
BERNAS:

Jurnal Pengabdian Kepada Masyarakat

Vol.1 No. 4, October 2020, pp. 531-542

tergolong baik. Terdapat 3 Indikator yang dijadikan penilaian yakni: (1) Keterampilan penyusunan data gambaran umum kondisi desa, (2) Keterampilan Analisis Isu Strategis Desa, (3) Keterampilan Perumusan Perencanaan Strategis. Dari 30 Peserta yang mengikuti kegiatan, terdapat 4 (empat) peserta memperoleh skor 86,67\%, 20 (dua puluh) peserta yang memperoleh skor $80 \%, 6$ (enam) peserta memperoleh skor 73,33\%. Dari hasil evaluasi tersebut menunjukkan bahwa perangkat desa telah memahami teknis dan aturan penyusunan RPJMDes tercermin dari hasil evaluasi yang masuk dalam kategori baik (minimal $80 \%$ ).

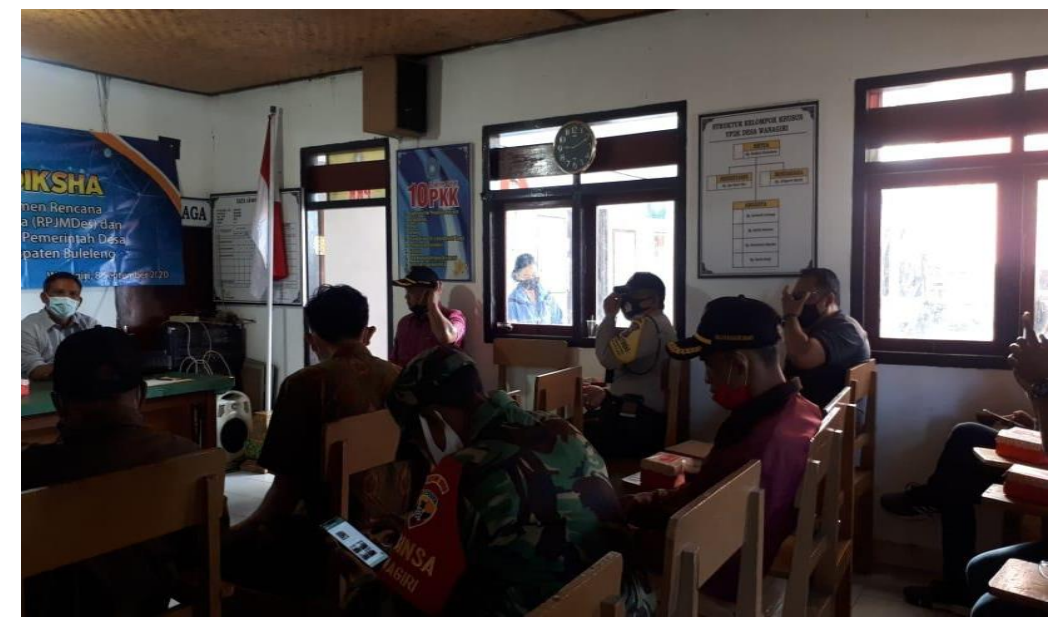

Gambar 4. Pelatihan dan Pendampingan Penyusunan RPJMDes

Kegiatan berikutnya dilanjutkan dengan pemberian pemahaman terkait manajemen keuangan desa. Pelaksanaan kegiatan ini terdiri dari tiga tahapan yakni tahapan persiapan, tahapan pelatihan dan pendampingan, serta tahapan evaluasi. Tahapan persiapan meliput penyiapan materi terkait dengan pertanggungjawaban dana desa, koordinasi waktu dan tempat, serta penyiapan perlengkapan lainnya yang digunakan dalam kegiatan pelatihan dan pendampingan.

Tahapan pelaksanaan kegiatan pelatihan dan pendampingan penyusunan pertanggungjawaban dana desa diawali dengan ceramah terkait pengelolaan keuangan desa (perencanaan sampai dengan pertanggungjawaban keuangan desa), regulasi pertanggungjawaban desa dan teknis pertanggungjawaban keuangan desa sesuai dengan peraturan yang berlaku.

Tahap akhir dalam kegiatan ini adalah tahap evaluasi kegiatan dengan memberikan pertanyaan berupa soal pilihan ganda kepada perangkat desa. Perangkat desa yang mampu menjawab minimal $80 \%$ benar dikatakan sudah memahami tentang penyusunan pertanggungjawaban dana desa sesuai dengan aturan yang berlaku. Dari 10 pertanyaan yang diajukan, 6 peserta memperoleh skor 90, sedangkan 16 peserta memperoleh skor 80 , dan 8 peserta memperoleh nilai 70 . Hasil evaluasi ini menunjukkan bahwa $73,33 \%$ peserta pelatihan dan pendampingan telah memahami teori penyusunan pertanggungjawaban dana desa. 


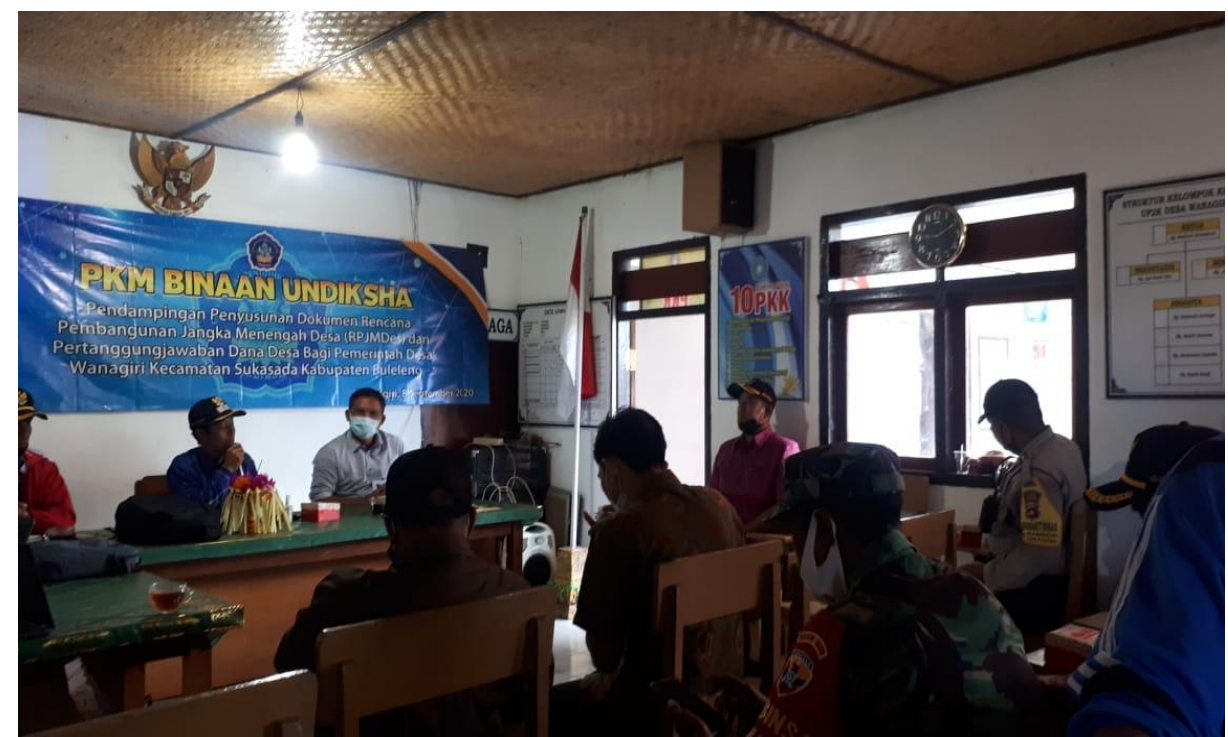

Gambar 5. Pemberian Pemahaman tentang Manajemen Keuangan Desa

Keberhasilan kegiatan ini berkat pelatihan dan pendampingan yang dilaksanakan secara bersinergi antara tim programmer dan tim pengabdi, serta perangkat Desa Wanagiri yang telah menyediakan fasilitas dalam menunjang pelaksanaan kegiatan pelatihan dan pendampingan.

\section{Kesimpulan}

Melalui program kegiatan pelatihan dan pendampingan yang diberikan dalam penyusunan profil desa, RPJMDes, dan pertanggungjawaban dana desa, perangkat desa yang semula cenderung kesulitan dalam menyediakan profil desa yang memadai mampu menyusun profil desa yang dapat digunakan sebagai dasar informasi untuk penyusunan rencana pembangunan desa. Selain itu, perangkat desa yang semula kesulitan dalam menyusun dan menerjemahkan visi dan misi kepala desa ke dalam RPJMDes, karena tidak tersedianya data profil desa terkini dan kemampuan yang belum memadai, kini mulai memahami teknis penyusunan RPJMDes. Perangkat Desa juga telah memahami aturan yang berlaku dalam pengelolaan anggaran desa. Target luaran yang dicapai melalui pelatihan dan pendampingan ini adalah meningkatnya kapasitas pemerintah desa dalam menjalankan fungsi manajemen pemerintah salah satunya manajemen perencanaan pembangunan desa dan pengelolaan keuangan desa. Dengan tersedianya informasi terkait kondisi atau status desa maka aparatur desa dapat merancang strategi yang tepat serta pemahaman terkait teknis penyusunan RPJMDes dan Pertanggungjawaban dana desa. Berdasarkan hasil perhitungan indeks desa membangun selama kegiatan pelatihan dan pendampingan, Desa Wanagiri termasuk dalam status Desa Berkembang. Dengan mengetahui kondisi desa saat ini, maka perangkat desa dapat menyusun kebijakan perencanaan pembangunan yang tepat untuk mengatasi permasalahan yang ada di Desa Wanagiri. Rencana tindak lanjut program pengabdian kepada masyarakat perlu memperhatikan beberapa aspek penting, diantaranya: (a) Memperbaharui secara berkala aplikasi yang digunakan untuk mengevaluasi kondisi desa, dan (b) memperpanjang waktu 
pendampingan sampai mampu menyusun dokumen RPJMDes dan Pertanggungjawaban Dana Desa secara terperinci dan lengkap.

\section{Daftar Pustaka}

Achsin, S. N., Cangara, H., \& Unde, A. A. (2016). Profil desa dan kelurahan sebagai sumber informasi: Studi evaluasi tentang penyediaan informasi potensi desa dan kelurahan di sulawesi selatan oleh badan pemberdayaan masyarakat pemerintahan desa dan kelurahan (BPMPDK) Provinsi Sulawesi selatan. KAREBA: Jurnal IImu Komunikasi, 4(4), 449-467.

Andrews, R., G. Boyne., J. Law., \& R. Walker. 2012. Strategic Management and Public Service Performance. London: Palgrave Macmillan.

Bandiyah (2016). Pelatihan Dan Pendampingan Penyusunan RPJMDesa Berbasis Partisipatif Di Desa Lokasari, Sidemen, Karangasem, Bali. Jurnal Pengabdian Pada Masyarakat Udayana, 1 (1): 11 - 17.

Harun, N. I., Rasid, A.U., \& Alamri, A. R. (2019). Pendampingan Penyusunan RPJMDes dan Pengelolaan BUMDes di Desa Dulukapa Kec. Sumalata Timur Kab. Gorontalo Utara. Insan Cita: Jurnal Pengabdian Kepada Masyarakat, 1(2).

Noor, M., Firdaus, M. R., \& Yopiannor, F. Z. (2019). Model Penguatan Kapasitas Pemerintah Desa Sebagai Agenda Utama Optimasi Pengelolaan Desa Menuju kemandirian (Studi Kasus Desa Maipe Kecamatan Paju Epat Kabupaten Barito Timur). Jurnal PubBis, 3(1), 66-86

Nugroho, S., Wijaya, A. F., \& Said, M. (2015). Pengembangan Kapasitas Aparatur Pemerintah Desa dalam Upaya Mewujudkan Good Governance. Jurnal Administrasi Publik (JAP), 1(5), 1010-1015.

Peraturan Menteri Dalam Negeri Nomor 12 Tahun 2007 tentang Pedoman Penyusunan dan Pendayagunaan Profil Desa dan Kelurahan.

Peraturan Menteri Dalam Negeri Nomor 81 Tahun 2015 tentang Evaluasi Perkembangan Desa.

Peraturan Menteri Desa, Pembangunan Daerah Tertinggal dan Transmigrasi Nomor 2 Tahun 2016 tentang Indeks Desa Membangun.

Putra, Z., Budianto, B., \& Maulidasari, C. D. (2018). PKM Pengelolaan Keuangan Desa Secara Profesional Menuju Desa yang Kuat dan Mandiri (Sasaran Program: Aparatur Pemerintah Gampong dalam Kecamatan Meureubo Kabupaten Aceh Barat Provinsi Aceh). RESONA: Jurnal IImiah Pengabdian Masyarakat, 2(2).

Setyobakti, M. H. (2017). Identifikasi masalah dan potensi desa berbasis Indek Desa Membangun (IDM) di desa gondowangi kecamatan wagir Kabupaten Malang. WIGA: Jurnal Penelitian IImu Ekonomi, ス1), 1-14.

Sulaiman Zuhdi, S. (2018). Pemetaan Data Dan Informasi Penyusunan Perencanaan Pembangunan Desa Di Kecamatan Tambang Kabupaten Kampar. Jurnal Niara, 11(2), 26-34.

Tampubolon, D. (2018). Pelatihan Dan Pendampingan Penyusunan Revisi RPJM Desa Kepenghuluan Bantaian Dan Bantaian Hilir Kecamatan Batu Hampar Kabupaten 
Rokan Hilir. In Prosiding Seminar Nasional Hasil Pengabdian (Vol. 1, No. 1, pp. 380385). 